\title{
GAMBARAN KADAR HEMATOKRIT DAN HEMOGLOBIN PADA KEJADIAN INFARK MIOKARD AKUT (IMA) DI RSUP PROF. DR. R. D. KANDOU MANADO PERIODE JANUARI - AGUSTUS 2014
}

\author{
${ }^{1}$ Fitri Jumalang \\ ${ }^{2}$ Linda W. A. Rotty \\ ${ }^{3 .}$ Agnes L. Panda
}

\author{
${ }^{1}$ Kandidat Skripsi Fakultas Kedokteran Universitas Sam Ratulangi \\ ${ }^{2}$ Bagian Ilmu Penyakit Dalam RSUP Prof. R. D. Kandou Manado \\ Fakultas Kedokteran Universitas Sam Ratulangi \\ Email : fjumalang_11_038@yahoo.co.id
}

\begin{abstract}
Acute myocardial infarction (AMI) or better known as a heart attack is a condition where the blood supply to a part of the heart stops so that the heart muscle cell death. Acute myocardial infarction is one of the most common diagnosis in developed countries. The rate of initial mortality (30 days) at the IMA is $30 \%$ with more than half of the deaths occur before the patient reaches the hospital. Methods - This research is a retrospective descriptive study. Samples were adult patients suffering from acute myocardial infarction who were treated in RSUP Prof. Dr R. D. Kandou. Results - Overview hematocrit and hemoglobin levels in the incidence of acute myocardial infarction in the department of Prof. Dr. RD Kandou Manado period January - August 2014 hemodilution patients get as many as 19 people (61.3\%) and patients with normal hematocrit many as 12 people (38.7\% ). In addition, for an overview of hemoglobin by age and sex obtained anemia patients by 5 people $(16.1 \%)$ and patients with normal hemoglobin many as 26 people (83.9\%). Conclusions - AMI patients in RSUP Prof. Dr RD Kandou Manado period January-August 2014 are subjected to low hematocrit (hemodilution) and normal hemoglobin.
\end{abstract}

Keywords: acute myocardial infarction, hematocrit, hemoglobin

\begin{abstract}
Abstrak: Infark miokard akut (IMA) atau yang lebih dikenal dengan serangan jantung adalah suatu keadaan dimana suplai darah pada suatu bagian jantung terhenti sehingga sel otot jantung mengalami kematian. Infark miokard akut merupakan salah satu diagnosis rawat inap tersering di negara maju. Laju mortalitas awal (30 hari) pada IMA adalah 30\% dengan lebih dari separuh kematian terjadi sebelum pasien mencapai Rumah Sakit. Metode - Penelitian ini merupakan penelitian deskriptif retrospektif. Sampel penelitian ini adalah penderita dewasa yang menderita infark miokard akut yang dirawat di RSUP Prof. Dr. R. D. Kandou. Hasil Gambaran kadar hematokrit dan hemoglobin pada kejadian infark miokard akut di RSUP Prof DR RD Kandou Manado periode januari - agustus 2014 didapatkan pasien hemodilusi sebanyak 19 orang $(61,3 \%)$ dan pasien hematokrit normal sebanyak 12 orang (38,7\%). Selain itu, untuk gambaran hemoglobin berdasarkan umur dan jenis kelamin didapatkan pasien yang anemia sebanyak 5 orang $(16,1 \%)$ dan pasien hemoglobin normal sebanyak 26 orang (83,9\%). Simpulan - Pasien IMA di RSUP Prof. Dr. R. D. Kandou Manado periode januari-agustus 2014 sebagian besar mengalami hematokrit rendah (hemodilusi) dan hemoglobin normal.
\end{abstract}

Kata kunci: infark miokard akut, hematokrit, hemoglobin

Satu juta orang di Amerika Serikat diperkirakan menderita infark miokard akut tiap tahunnya dan 300.000 orang meninggal karena infark miokard akut sebelum sampai ke rumah sakit. ${ }^{1}$ Penyakit kardiovaskuler dinyatakan sebagai 
penyebab kematian utama dengan kontribusi sebesar 19,8\% dari total kematian pada tahun 1993 dan meningkat menjadi 24,4\% pada tahun 1998. Pada tahun 2005, diperkirakan 17,5 juta orang (30\% dari total angka kematian) meninggal akibat penyakit kardiovaskuler. Di Indonesia, hasil survei kesehatan rumah tangga menunjukkan hal senada. ${ }^{2}$ Penyakit Jantung Koroner (PJK) merupakan penyebab kematian nomor satu di Eropa dan Amerika begitu juga di Indonesia, baik untuk laki-laki maupun wanita. Angka kesakitan dan angka kematian PJK di Indonesia meningkat tajam dalam dua puluh tahun terakhir ini, sebagai mana terlihat pada Survei Kesehatan Rumah Tangga (SKRT). ${ }^{3}$ Data Survey Kesehatan Rumah Tangga tahun 1996 menunjukkan bahwa proporsi penyakit ini meningkat dari tahun ke tahun sebagai penyebab kematian. Pada tahun 1975 kematian akibat penyakit jantung hanya 5,9\%, tahun 1981 meningkat sampai dengan 9,1\%, tahun 1986 melonjak menjadi 16\% dan tahun 1995 meningkat menjadi 19\%. Sensus nasional tahun 2001 menunjukkan bahwa kematian karena penyakit kardiovaskuler termasuk penyakit jantung koroner adalah sebesar 26,4\%. ${ }^{4}$

Infark miokard akut merupakan salah satu diagnosis rawat inap tersering di negara maju. Laju mortalitas awal (30 hari) pada IMA adalah 30\% dengan lebih dari separuh kematian terjadi sebelum pasien mencapai Rumah Sakit. Walaupun laju mortalitas menurun sebesar 30\% dalam 2 dekade terakhir, sekitar 1 di antara 25 pasien yang tetap hidup pada perawatan awal, meninggal dalam tahun pertama setelah IMA. ${ }^{5}$

Hematokrit adalah persentase sel darah merah dalam darah, yang dihitung dengan mengikutsertakan baik jumlah maupun

\section{METODE PENELITIAN}

\section{A. Rancangan Penelitian}

Penelitian ini merupakan penelitian deskriptif retrospektif. ukuran sel-sel tersebut dan dinyatakan sebagai persentase terhadap volume darah. ${ }^{6}$ Nilai normal hematokrit pada perempuan berkisar 37-48 \%, sedangkan pada laki-laki berkisar $42-52 \%$. Keadaan-keadaan yang dapat menyebabkan peningkatan hematokrit adalah luka bakar, penyakit kardiovaskuler, penyakit paru kronik, defek jantung kongenital, syok dan lain-lain. Sebaliknya, hematokrit menurun pada penderita anemia, sirosis hati, perdarahan, leukemia, penyakit Addison, infeksi kronik dan lain-lain. $^{7}$

Sel-sel darah merah mampu mengonsentrasikan hemoglobin dalam cairan sel sampai sekitar 34 gram per 100 mililiter sel. Konsentrasi ini tidak akan melebihi nilai tersebut, karena nilai ini merupakan batas metabolik mekanisme pembentukan hemoglobin sel. Selanjutnya, pada orang normal, persentase hemoglobin hampir selalu mendekati nilai maksimum dalam setiap sel. Namun, bila pembentukan hemoglobin dalam sumsum tulang berkurang, persentase hemoglobin dalam sel dapat turun sampai di bawah nilai tersebut, dan volume sel darah merah juga dapat menurun karena jumlah hemoglobin yang mengisi sel menjadi berkurang. Bila hematokrit (persentase sel dalam darah normalnya 40 sampai 45 persen) dan jumlah hemoglobin dalam masing-masing sel bernilai normal, maka seluruh darah seorang pria rata-rata mengandung 15 gram hemoglobin per 100 mililiter sel; pada wanita rata-rata mengandung 14 gram per 100 mililiter sel. ${ }^{8}$ Pada perempuan hemoglobin normal berkisar 12 gr/dL dan pada laki-laki berkisar $13 \mathrm{gr} / \mathrm{dL}$.

Berdasarkan latar belakang tersebut penulis tertarik untuk melakukan penelitian mengenai gambaran kadar hemaokrit dan hemoglobin pada Infark Miokard Akut.

\section{B. Tempat dan Waktu Penelitian}

Penelitian dilaksanakan di Bagian/SMF Penyakit Dalam RSUP Prof. Dr. R. D. Kandou pada bulan Oktober - Desember 2014. 


\section{Populasi dan Sampel Penelitian}

Populasi dari penelitian ini adalah penderita infark miokard akut di RSUP Prof. Dr. R. D. Kandou. Sampel penelitian ini adalah penderita dewasa yang menderita infark miokard akut.

D. Analisis Data

Analisis univariat untuk mengetahui deskripsi data yang diperoleh dari rekam medis penderita Infark Miokard Akut.

\section{E. Definisi Operasional}

1. Infark Miokard Akut (IMA) merupakan gangguan aliran darah ke jantung yang menyebabkan sel otot jantung mati.

2. Hematokrit adalah persentase sel darah merah dalam darah, yang

\section{HASIL PENELITIAN}

Hasil penelitian tentang gambaran kadar hematokrit dan hemoglobin pada kejadian Infark Miokard Akut (IMA) di RSUP Prof. DR. R.D. Kandou Manado Periode Januari - Agustus 2014 disajikan dalam bentuk analisis univariat yang mencakup tentang karakteristik jenis dihitung dengan mengikutsertakan baik jumlah maupun ukuran sel-sel tersebut dan dinyatakan sebagai persentase terhadap volume darah, dimana nilai hematokrit normal pada perempuan 37-48\% dan pada laki-laki 42-52\%.

3. Hemoglobin adalah seperangkat protein yang sangat berkaitan erat dibentuk oleh pasangan simetris dimer rantai polipeptida, $\alpha$ - dan $\beta$-globin, menjadi unit struktural dan fungsional tetrameric yang berfungsi mengangkut okssigen (O2) dari paru-paru ke jaringan. Nilai normal hemoglobin pada perempuan $12 \mathrm{mg} / \mathrm{dL}$ dan pada laki-laki $13 \quad \mathrm{gr} / \mathrm{dL}$.

kelamin, umur, kadar hematokrit, kadar hemoglobin, nilai mean, standar deviasi, nilai minimum dan maksimum, hasil deskriptif tabulasi silang variabel hematokrit dan hemoglobin terhadap umur dan hasil deskriptif tabulasi silang variabel hematokrit dan hemoglobin terhadap jenis kelamin pada 31 responden yang terpilih.

\section{A. Karakteristik Jenis Kelamin}

Tabel 1. Distribusi Frekuensi BerdasarkanJenis Kelamin

\begin{tabular}{ccc}
\hline Jenis kelamin & N & $\%$ \\
\hline Laki-laki & 23 & 74,2 \\
Perempuan & 8 & 25,8 \\
Total & 31 & 100
\end{tabular}

Berdasarkan Tabel 1 dapat dilihat bahwa laki-laki yang berjumlah 23 orang $(74,2 \%)$ sebagian besar responden yang dijadikan dan perempuan berjumlah 8 orang (25,8\%). sampel penelitian adalah berjenis kelamin

\section{B. Karakteristik Umur}

Tabel 2. Distribusi Frekuensi Berdasarkan Umur

\begin{tabular}{ccc}
\hline Kategori Umur & $\mathrm{N}$ & $\%$ \\
\hline $36-45$ tahun & 2 & 6,5 \\
$46-55$ tahun & 12 & 38,7 \\
$55-65$ tahun & 10 & 32,3 \\
$>65$ tahun & 7 & 22,6 \\
Total & 31 & 100 \\
\hline
\end{tabular}

Berdasarkan Tabel 2 dapat dilihat bahwa sebagian besar responden yang dijadikan sampel penelitian berada pada kategori umur 46-55 tahun yang berjumlah 12 orang 
(38,7\%), kategori umur 55-65 tahun berjumlah 10 orang (32,3\%), kategori umur $>65$ tahun berjumlah 7 orang $(22,6 \%)$ dan kategori umur 36-45 tahun berjumlah 2 orang $(6,5 \%)$.

\section{Karakteristik Hematokrit}

Tabel 3. Distribusi Frekuensi Berdasarkan Kadar Hematokrit

\begin{tabular}{lll}
\hline Kadar hematokrit & $\mathrm{N}$ & $\%$ \\
\hline Hemodilusi & 19 & 61,3 \\
Normal & 12 & 38,7 \\
Total & 31 & 100
\end{tabular}

Berdasarkan Tabel 3 dapat dilihat bahwa sebagian besar responden yang dijadikan sampel penelitian memiliki kadar hematokrit yang kurang (hemodilusi) yang berjumlah 19 orang (61,3\%) dan yang memiliki kadar hematokrit normal berjumlah 12 orang (38,7\%).

\section{Karakteristik Hemoglobin}

Tabel 4. Distribusi Frekuensi Berdasarkan Kadar Hemoglobin

\begin{tabular}{ccc}
\hline Kadar hemoglobin & $\mathrm{N}$ & $\%$ \\
\hline Anemia & 5 & 16,1 \\
Normal & 26 & 83,9 \\
Total & 31 & 100 \\
\hline
\end{tabular}

Berdasarkan Tabel 4 dapat dilihat bahwa sebagian besar responden yang dijadikan sampel penelitian memiliki kadar hemoglobin yang normal yang berjumlah 26 orang (83,9\%) dan memiliki kadar hemoglobin yang kurang (anemia) berjumlah 5 orang $(16,1 \%)$.

\section{E. Hasil Deskriptif Hematokrit Berdasarkan Umur Responden}

Dari 31 responden penelitian sebagian besar responden dengan kadar hematokrit yang kurang (hemodolusi) berada pada kategori umur 46-55 tahun dan 56-65 tahun masing-masing sebanyak 8 orang $(25,8 \%)$ sedangkan sebagian besar responden dengan kadar hematokrit yang normal berada pada kategori umur 46-55 tahun dan $>65$ tahun masing-masing sebanyak 4 orang (12,9\%).

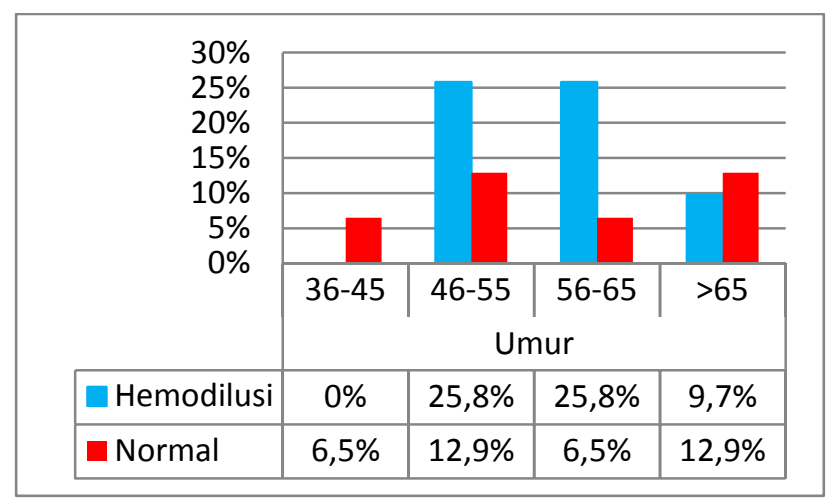

Gambar 1. Gambaran hematokrit berdasarkan umur

\section{F. Hasil Deskriptif Hemoglobin Berdasarkan Umur Responden}

Berdasarkan umur dari 31 responden penelitian sebagian besar dengan kadar hemogobin yang normal berada pada kategori umur 46-55 tahun sebanyak 11 orang $(35,5 \%)$ sedangkan sebagian besar responden dengan kadar hemoglobin yang kurang (anemia) berada pada kategori umur 56-65 tahun dan > 65 tahun masing-masing sebanyak 2 orang (6,5\%). 


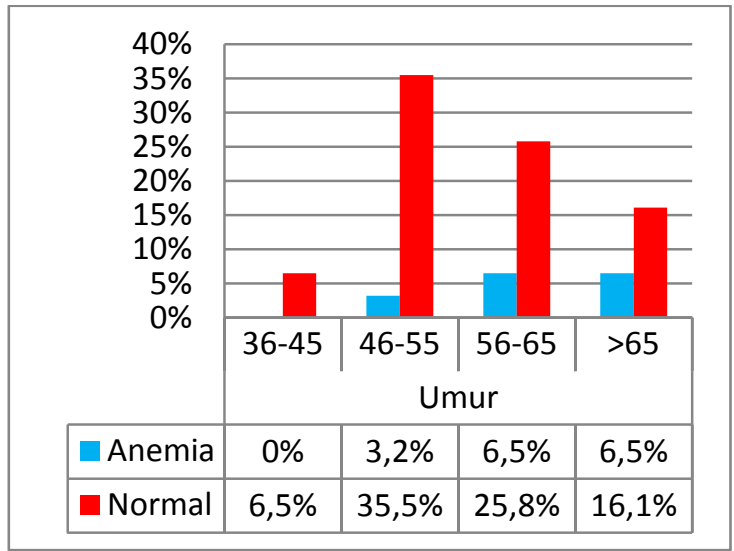

Gambar 2. Hasil persentase hemoglobin berdasarkan umur

\section{G. Hasil Deskriptif Hematokrit Berdasarkan Jenis Kelamin}

Dari 31 responden penelitian sebagian besar responden dengan kadar hematokrit yang kurang (hemodolusi) mempunyai jenis kelamin laki-laki sebanyak 16 orang (51,6\%) dan perempuan sebanyak 3 orang $(9,7 \%)$ sedangkan sebagian besar responden dengan kadar hematokrit yang normal mempunyai jenis kelamin laki-laki sebanyak 7 orang $(22,6 \%)$ dan perempuan sebanyak 5 orang $(25,8 \%)$.

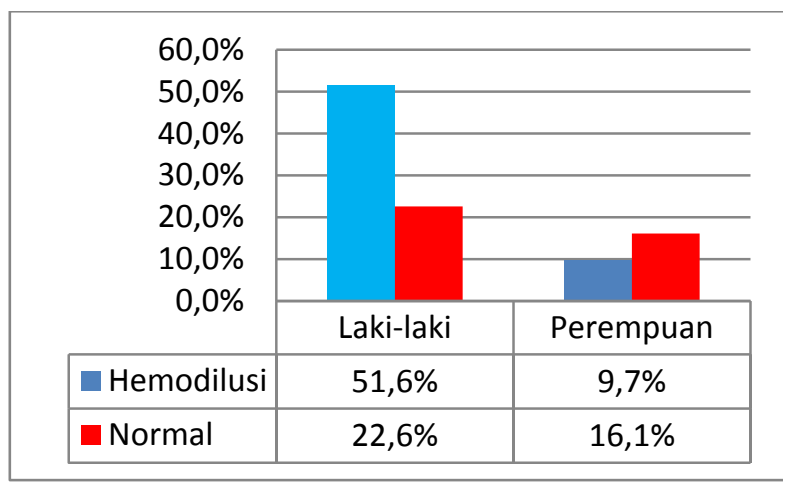

Gambar 3. Hasil persentase hematokrit berdasarkan jenis kelamin

\section{H. Hasil Deskriptif Hemoglobin Berdasarkan Jenis Kelamin}

Dari 31 responden penelitian sebagian besar responden dengan kadar hematokrit yang normal mempunyai jenis kelamin laki-laki sebanyak 19 orang (61,3\%) dan perempuan sebanyak 7 orang (22,6\%) sedangkan sebagian besar responden dengan kadar hematokrit yang kurang (anemia) mempunyai jenis kelamin lakilaki sebanyak 4 orang (12,9\%) dan perempuan sebanyak 1 orang (3,2\%).

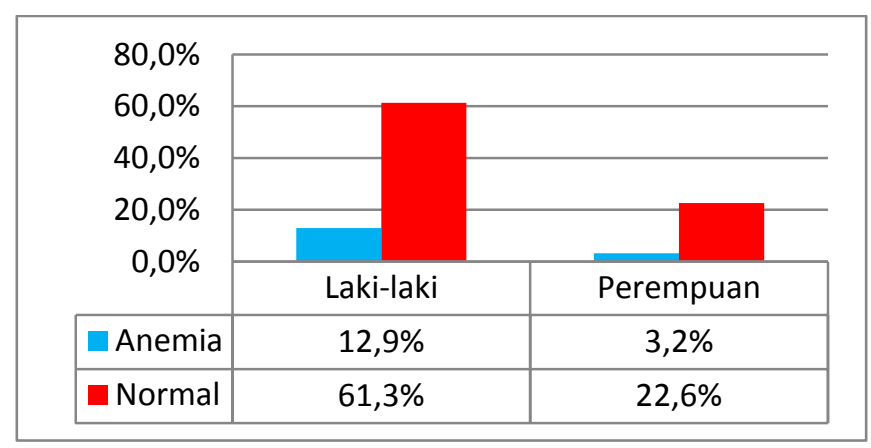

Gambar 4. Hasil persentase hemoglobin berdasarkan jenis kelamin

\section{Nilai Mean, Standar Deviasi (SD), Minimum dan Maksimum Nilai Hasil Pengukuran}

Tabel 5. Nilai Mean, SD, Minimum dan Maksimum

\begin{tabular}{ccccc}
\hline & Mean & SD & Mini & Maks \\
& & & & \\
\hline Hematokrit & 39,77 & 5,30 & 28 & 49,9 \\
Hemoglobin & 13,62 & 1,53 & 10,4 & 16,0 \\
\hline
\end{tabular}

Berdasarkan Tabel 5 dapat dilihat bahwa rata-rata (mean) kadar hematokrit adalah 39,77, nilai SD 5,3, nilai minimum 28 dan maksimum 49,9. Nilai rata-rata (mean) kadar hemoglobin adalah 13,62, nilai SD 1,53, nilai minimum 10,4 dan maksimum 16,0. 


\section{BAHASAN}

Pada penelitian gambaran kadar hematokrit dan hemoglobin pada kejadian Infark Miokard Akut di RSUP Prof Dr. R. D. Kandou Manado periode Januari 2014 Agustus 2014, dari 31 pasien didapatkan 23 pasien penderita IMA adalah laki-laki. Pasien IMA sebagian besar terdiri dari laki-laki dewasa disebabkan oleh kebiasaan merokok dan juga faktor resiko lainnya seperti yang disebutkan di atas dan terbanyak terjadi pada umur $>46$ tahun. Menurut penelitian Fonarow G, dari school of medicine at the university of california, Los Angeles, seseorang dapat mengalami serangan jantung tanpa faktor resiko lain jika seseorang tersebut merokok, atau bila Anda hanya seorang perokok, atau mempunyai salah satu faktor resiko seperti hipertensi atau kolesterol tinggi, Anda mempunyai risiko untuk mengalami serangan jantung 2 kali lebih besar dari populasi yang normal. ${ }^{9}$

Pada penelitian sebelumnya mengenai faktor-faktor yang mempengaruhi kejadian kardiovaskular mayor pada wanita pasca infark miokard akut didapatkan perempuan pasca IMA dalam rentang waktu pengamatan 14-26 bulan didapati angka kejadian kardiovaskular mayor sebesar 51,7\%. Pada kelompok perempuan usia tua ( $\geq 55$ tahun) didapatkan adanya kejadian kardiovaskular mayor yang lebih tinggi daripada kelompok usia yang lebih muda $(\leq 55$ tahun). Pada kelompok perempuan usia tua ( $>55$ tahun) dipengaruhi oleh adanya DM, riwayat angina pektoris stabil sebelum IMA dan lesi koroner $3 \mathrm{VD} / \mathrm{LM}$ disease. ${ }^{10}$ Dari hasil yang didapatkan berhubungan dengan penelitian yang dilakukan penulis dimana berdasarkan data rekam medis pasien di RSUP Prof. Dr. R. D. Kandou kejadian IMA pada wanita terjadi sebagian besar pada usia tua.

Berdasarkan penelitian, gambaran hematokrit pada kejadian IMA berdasarkan umur dan jenis kelamin responden didapatkan pasien hemodilusi sebanyak 19 orang (61,3\%) dan pasien hematokrit normal sebanyak 12 orang (38,7\%). Selain itu, untuk gambaran hemoglobin berdasarkan umur dan jenis kelamin didapatkan pasien yang anemia sebanyak 5 orang $(16,1 \%)$ dan pasien hemoglobin normal sebanyak 26 orang (83,9\%). Jadi, gambaran hematokrit pada kejadian IMA berdasarkan umur dan jenis kelamin didapatkan pasien hemodilusi lebih banyak dibanding hematokrit normal dan untuk gambaran hemoglobin didapatkan pasien dengan hemoglobin normal lebih banyak dibanding anemia.

Menurut penelitian Mita E. D. Muabuay yang juga dilakukan pada tahun 2012 di RSUP Prof R. D. Kandou menemukan adanya hubungan antara hematokrit dan infark miokard akut pada pasien gagal jantung kongestif. ${ }^{11}$

\section{SIMPULAN}

Dari hasil penelitian ini dapat diambil kesimpulan, yaitu pada pasien IMA di RSUP Prof. Dr. R. D. Kandou Manado periode januari-agustus 2014 sebagian besar mengalami hematokrit rendah (hemodilusi) dan hemoglobin normal.

\section{SARAN}

Mengingat bahwa penelitian ini tidak mencari hubungan dari kadar hematokrit dan hemoglobin pada kejadian infark miokard akut, maka disarankan :

1. Penelitian selanjutnya diarahkan untuk mencari hubungan.

2. Penelitian selanjutnya mencari data selain dari rekam medis juga dari pasien langsung

\section{DAFTAR PUSTAKA}

1. Christofferson RD. Acute Myocardial Infarction. In : Griffin

BP, Topol EJ, eds. Manual of cardiovascular medicine. 3rd ed. Philadelphia: Lippincot Williams \& Wilkins. 2009. p.1-28 
2. Perwitasari DA, Supadmi Woro, Kurniyati. Monitoring Efek Samping Penggunaan Antitrombotik pada Pasien Infark Miokard Akut. Yokyakarta: Jurnal Farmasi Indonesia, Universitas Ahmad Dahlan. 2010;5:914.

3. Hasan H. Intervensi Koroner Perkutan Pada Penyakit Jantung Koroner dan Permasalahannya. Medan: Fakultas Kedokteran USU; 2007.

4. Farissa P. I. Komplikasi pada Pasien Infark Miokard Akut ST-Elevasi (Stemi) yang Mendapat Maupun Tidak Mendapat Terapi Reperfusi (Skripsi). Semarang: Fakultas Kedokteran UNDIP. 2012. p.1-10

5. Sudoyo AW, Setiyohadi B, Alwi I, Simadibrata M, Setiati S. Buku Ajar Ilmu Penyakit Dalam. Edisi ke-5. Jakarta: InternaPublishing Pusat Penerbitan Ilmu Penyakit Dalam. 2009.

6. Mehmet, Roizen M. You Staying YoungL: The owners's Manual Extending Your Warranty. New York: Simon \& Schuster. 2007.

7. Wilson DD. McGraw-Hill's Manual of Laboratory \& Diagnostic Test. Boston: McGraw-Hill’s Companies. 2008.
8. Kul NA, Ozdemir S, Helvaci A, Bulut C, Dursun S,. The Relationship of Acute Myocardial Infarction With or Without ST-Segment Elevation and Viscosity. Clinical and Applied Thrombosis/Hemostasis. 2014;20(8):779-82.

9. Kalalo GF, Pangemanan Jandry, Panda AL. Pengaruh Gaya Hidup Merokok Terhadap Kejadian Infark Miokard Akut (IMA) di RSU Bethesda Tomohon (Skripsi). Manado: Fakultas Kedokteran Universitas Sam Ratulangi. 2012.

10. Danny Siska S, Roebiono Poppy S, Soesanto Amilia M, Kasim Manoefris. Faktor-Faktor yang Mempengaruhi Kejadian Kardiovaskular Mayor pada Wanita Pasca Infark Miokard Akut. Jurnal Kardiologi Indonesia. 2009;30:3-12.

11. Muabuay Mita. Hubungan Kadar Hematokrit Dengan Kejadian Infark Miokard Akut Pada Pasien Gagal Jantung Kongestif di BLU/RSUP Prof. Dr. R. D. Kandou Manado (Skripsi). Manado: Fakultas Kedokteran Unsrat. 2013. 